\title{
FITOKIMIA DAN POTENSI ANTIOKSIDAN DAUN JEMBELU (Embelia sp.) TANAMAN OBAT DARI KABUPATEN KUTAI KARTANEGARA
}

\author{
Purwati $^{1}$, Yossy Marsella ${ }^{2}$ \\ ${ }^{1,2}$ Program Studi Agroteknologi, Fakultas Pertanian, Universitas Widya Gama Mahakam, \\ Indonesia. \\ E-Mail: ${ }^{1}$ purwati@uwgm.ac.id
}

\begin{abstract}
ABSTRAK
Fitokimia dan Potensi Antioksidan Daun Jembelu (Embelia sp.) Tanaman Obat dari Kabupaten Kutai Kartanegara. Daun jembelu telah dimanfaatkan oleh masyarakat Kalimantan Timur sebagai penambah citarasa pada masakan dan bermanfaat untuk menurunkan kadar kolesterol pada olahan daging. Pemanfaatan daun jembelu sebagai tanaman obat perlu didukung melalui penelitian sehingga khasiatnya dapat dipertanggungjawabkan secara ilmiah. Penggunaan tanaman obat memiliki kelebihan diantaranya harga lebih murah, aman dan lebih sedikit efek samping. Penelitian bertujuan untuk mengetahui kandungan fitokimia dan potensi antioksidan daun jembelu dari Kabupaten Kutai Kartanegara sebagai tanaman obat. Penelitian ini menggunakan metode analisis data dilakukan secara deskriptif kualitatif dan kuantitatif dalam bentuk tabulasi dan gambar. Pengujian aktivitas antioksidan dilakukan dengan menggunakan metode DPPH dan gambaran aktivitas antioksidan yaitu dinyatakan dengan $\mathrm{IC}_{50}$. Hasil yang didapat lalu dihitung dengan menggunakan analisis data regresi linier.

Hasil penelitian menunjukkan bahwa senyawa aktif yang terdapat dalam daun jembelu meliputi alkaloid, fenolik dan steroid. Ekstrak metanol daun jembelu memiliki aktivitas antioksidan yang rendah dengan nilai $\mathrm{IC}_{50}$, sebesar $85.206 \mathrm{ppm}$.
\end{abstract}

Kata kunci : Antioksidan, Daun Jembelu, Fitokimia.

\begin{abstract}
Phytochemical and Antioxidant Potential of Jembelu Leaves (Embelia sp.) of Medicinal Plant from Kutai Kartanegara District. Jembelu leaves have been used by the people of East Kalimantan as a flavor enhancer in cooking and are useful for reducing cholesterol levels in processed meat. The use of jembelu leaves as a medicinal plant needs to be supported through research so that its properties can be scientifically justified. The use of medicinal plants has advantages including lower prices, safer and fewer side effects. The study aims to determine the phytochemical content and antioxidant potential of jembelu leaves from Kutai Kartanegara District as a medicinal plant. This study uses data analysis methods carried out in a descriptive qualitative and quantitative form of tabulation and images. Testing of antioxidant activity was carried out using the DPPH method and the description of antioxidant activity was stated by $I C_{50}$. The results obtained are then calculated using linear regression data analysis.

The results showed that the active compounds contained in jembelu leaves included alkaloids, phenolics and steroids. The methanol extract of jembelu leaves has a low antioxidant activity with an IC ${ }_{50}$ value of 85,206 ppm.
\end{abstract}

Key words : Phytochemical, Antioxidant, Jembelu Leaves.

\section{PENDAHULUAN}

Indonesia merupakan negara tropis yang memiliki berbagai jenis tumbuhan yang berkhasiat obat-obatan. Penggunaan tumbuhan obat untuk menyembuhkan berbagai penyakit mulai diminati di berbagai negara karena memiliki efek samping yang rendah dan tidak berbahaya bagi tubuh manusia. Senyawa fitokimia yang terdapat pada tumbuhan 
obat bersifat metabolit sekunder diantaranya fenol, alkaloid, steroid, glikosida, flavonoid dan pigmen tertentu.

Tanaman obat yang tumbuh secara liar dan belum tergali potensinya serta merupakan sumberdaya plasma nutfah yang belum dikembangkan. Hal ini disebabkan belum tersedianya data serta informasi yang lengkap tentangkeberadaannya, karakteristik dan lingkungan tumbuh yang mempengaruhinya. Informasi jenis tanaman dari masing-masing tanaman obat sangatpenting bagi pengembangan pangan fungsional.

Upaya yang dapat dilakukan dalam meningkatkan nilai ekonomi tumbuhan yaitu dengan mengetahui kandungan senyawa organik melalui analisis fitokimia. Penelitian mengenai senyawa bahan alam hayati memegang peranan penting dalam pemanfaatan senyawa kimia berkhasiat obat yang terdapat di alam. Penggunaan tumbuh-tumbuhan sebagai obat herbal merupakan warisan sejak dulu hingga sekarang. Bahan obat yang digunakan pada umumnya berasal dari daun, batang, akar, bunga, buah dan biji-bijian. Senyawa aktif yang terkandung dalam tumbuhan merupakan senyawa metabolit sekunder yaitu tanin, terpenoid, steroid, flavonoid, terpenoid dan alkaloid. Senyawa metabolit sekunder telah banyak digunakan sebagai zat warna, racun, aroma makanan dan obat-obatan (Lenny, 2006).

Pemanfaatan tumbuhan obat oleh masyarakat umumnya tidak mengetahuikandungan kimia tumbuhan tersebut dan masyarakatdalam penggunaan jumlah dosisnya ditentukandengan mengandalkan pengalaman dan perkiraan saja. Kandungan senyawa kimia dalamobat tradisional yang dikonsumsi tanpa mengetahui takaran dosis penggunaannya dapat menyebabakan efek samping yang merugikan. Uji kandungan kimia dilakukan melalui analisis fitokimia atau uji warna secara kualitatif.

Tanaman jembelu merupakan tanaman semak merambat atau liana dan daunnya dapat dimanfaatkan sebagai campuran sayur asam (Mukhlisi dkk, 2018).

Daun jembelu merupakan bahan alam yang telah dimanfaatkan oleh sebagian masyarakat di Kabupaten Kutai Kartanegarasebagai bahan campuran atau penambah citarasa (food flavour) pada masakan daging. Kandungan senyawa alami yang terdapat dalam daun jembelu diduga bermanfaat untuk menurunkan kadar kolesterol pada masakan daging. Sehingga masyarakat tidak perlu khawatir terhadap peningkatankadar kolesterol dalam darah ketika mengkonsumsi masakan daging. Sehingga penambahan daun jembelu sangat dianjurkan pada masakan daging karena bermanfaat untuk menjaga kesehatan.

Pemanfaatan daun jembelu sebagai tanaman obat dan bahan campuran pada masakan ini perlu didukung melalui penelitian sehingga khasiatnya dapat dipertanggungjawabkan secara ilmiah sehingga pemanfaatan dan pengembangan tumbuhan obat dapat diketahui secara luas oleh masyarakat.

Penelitian ini bertujuan untuk mengetahui kandungan senyawa fitokimia dan aktivitas antioksidan daun jembelu. Hasil penelitian ini diharapkan dapat memberikan kontribusi bagi pengembangan kimia bahan alam tentang tanaman yang mengandung senyawa metabolit sekunder.

\section{METODA PENELITIAN}

\subsection{Tempat dan Waktu}

$\begin{array}{llr}\begin{array}{l}\text { Penelitian } \\ \text { antioksidan }\end{array} & \text { uji } & \begin{array}{l}\text { fitokimia } \\ \text { dilakukan }\end{array} \\ \begin{array}{llr}\text { Laboratorium } & \text { dan } \\ \text { Fakultas } & \text { Kimia } & \text { Organik } \\ \text { MIPA } & \text { Universitas }\end{array}\end{array}$


Mulawarman Samarinda selama 2 (dua) bulan pada tahun 2019 .

\subsection{Metode Penelitian}

Koleksi bahan tanaman
Bahan tanaman yang digunakan dalam penelitian ini adalah daun jembelu tumbuhan lokal di KecamatanSanga-Sanga Kabupaten Kutai Kartanegara yang dikumpulkan pada bulan Nopember 2019.

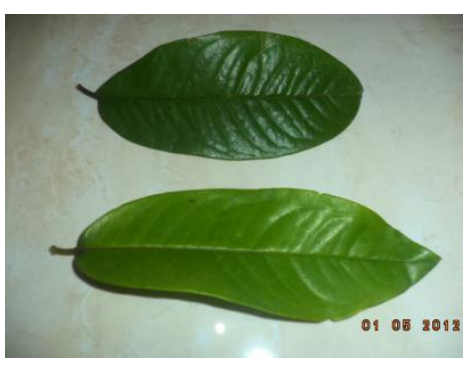

Gambar 1. Daun Jembelu

Preparasi Sampel

Sampel yang digunakan adalah daun jembelu yang diambil di Kecamatan Sanga-Sanga, Kabupaten Kutai
Kartanegara. Sampel dibersihkan dan dikering anginkan selama 10 hari dan dihaluskan dengan blender.

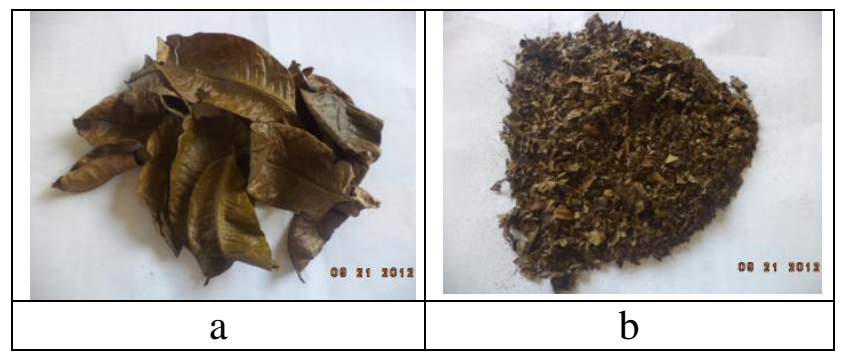

Gambar 2. a. Daun Jembelu Kering; b. Daun Jembelu yang telah Dihaluskan

Maserasi dan Ekstraksi

Sampel dimaserasi dengan etanol 95\% selama $3 \times 24$ jam pada suhu kamar. Ekstrak etanol yang diperoleh dikumpulkan dan diuapkan dengan evaporator hingga diperoleh ekstrak etanol kental dan ditimbang.

\section{Identifikasi}

Ekstrak etanol daun jembelu dilakukan skrining fitokimia bertujuan untuk mengetahui kandungan senyawa metabolit sekunder meliputi alkaloid, flavanoid, fenolik, steroid, triterpenoid dan saponin.

\section{Uji Alkaloid}

Ekstrak sampel dilakukan uji dengan pereaksi Dragendorff, Mayer dan Wagner. Jika terbentuk endapan berwarna merah bata dengan pereaksi Dragendorff, endapan berwarna putih dengan pereaksi Mayer dan endapan berwarna coklat dengan pereaksi Wagner menunjukkan adanya golongan senyawa alkaloid. 
Uji Flavonoid

Ekstrak sampel yang telah diuji, jika menunjukkan warna merah, kuning atau jingga pada lapisan amil alkohol membuktikan adanya senyawa golongan flavonoid.

\section{Uji Fenolik}

Ekstrak sampel yang telah diuji dengan larutan $\mathrm{FeCl}_{3} \quad 1 \%$ akan menunjukkan terbentuknya warna hijau, merah, ungu, biru tua, biru, biru kehitaman, atau hijau kehitaman.

Uji Steroid dan Triterpenoid

Ekstrak sampel yang diuji dengan pereaksi Liebermann-Burchard akan memperlihatkan terbentuknya warna merah atau hijau yang menunjukkan adanya senyawa golongan steroid atau triterpenoid.

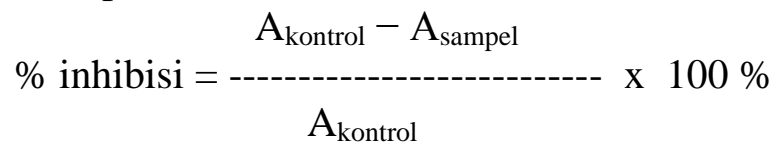

Uji Saponin

Ekstrak sampel yang telah diuji akan terbentuk busa yang stabil selama 10 menit dan tidak hilang pada penambahan $\mathrm{HCl} 2 \mathrm{~N}$, menunjukan adanya senyawa golongan saponin.

Penentuan Aktivitas Antioksidan

Aktivitas antioksidan dianalisa dengan membuat larutan DPPH (1,1diphenyl-2-phikril-hidrazil) dengan melarutkan kristal DPPH kedalam methanol.

Sampel diukur absorbansinya pada panjang gelombang517 nm.KemudianInhibition

Concentration $\left(\mathrm{IC}_{50}\right) \quad(\%)$ dihitung dengan persamaan :

Keterangan:

$\mathrm{A}_{\mathrm{kontrol}}=$ Absorbansi tidak mengandung sampel

$\mathrm{A}_{\text {sampel }}=$ Absorbansi sampel

\section{HASIL PENELITIAN DAN}

\section{PEMBAHASAN \\ Hasil Uji Fitokimia Daun Jembelu disajikan pada Tabel 1 dan Tabel 2.}

\section{Uji Fitokimia}

Tabel 1. Uji Fitokimia Ekstrak Daun Jembelu

\begin{tabular}{lcccc}
\hline & \multicolumn{4}{c}{ Golongan Senyawa } \\
\cline { 2 - 4 } & Flavonoid & Kuinon & Alkaloid & Fenolik \\
\hline Hasil Pengujian & + & - & - & + \\
\hline
\end{tabular}

Keterangan : (+) terkandung dalam sampel;

(-) tidak terkandung dalam sampel 
Tabel 2. Uji Fitokimia Ekstrak Daun Jembelu

\begin{tabular}{lccc}
\hline & & Golongan Senyawa \\
\cline { 2 - 4 } & Steroid & Triterpenoid & Saponin \\
\hline Hasil Pengujian & + & - & - \\
& & & \\
\hline
\end{tabular}

Keterangan : (+) terkandung dalam sampel;

(-) tidak terkandung dalam sampel

Analisis kandungan senyawa kimia melalui ekstrak etanol sampel daun jembelu dengan tes uji warna menggunakan beberapa pereaksi yang bertujuan mengetahui senyawa fitokimia tersebut.

Hasil uji fitokimia ekstrak etanol daun jembelu menunjukkan bahwa sampel daun mengandung senyawa flavonoid. Hal ini dapat dilihat dari hasil tes uji warna yang berwarna hijau muda. Senyawa flavonoid merupakan antioksidan alami yang berperan dalam menangkal radikal bebas sehingga dapat mencegah pemicu sel kanker. Mencegah pengeroposan tulang, antibiotik dan meningkatkan efektivitas vitamin $\mathrm{C}$.

Hasil uji fitokimia ekstrak etanol daun jembelu menunjukkan terdapat senyawa fenolik. Hal ini dapat dilihat dari hasil tes uji warna yang berwarna coklat kehitaman. Senyawa fenolik memiliki cincin aromatik meliputi senyawa fenol.

Hasil uji fitokimia ekstrak etanol daun jembelu menunjukkan adanya senyawa steroid. Hal ini dapat dilihat dari hasil tes uji warna yaitu terbentuk cincin berwarna hijau. Fungsi senyawa steroid dalam tumbuhan adalah sebagai pelindung terhadap serangan patogen bagi tanaman. Steroid berperan sebagai hormon dalam tubuh yang berfungsi untuk menurunkan kolesterol dan membentuk otot yang besar dan kuat.

\section{Uji Antioksidan}

Hasil uji aktivitas antioksidan menunjukkan bahwa sampel daun jembelu menunjukkan aktivitas antioksidan yang sangat rendah karena memiliki nilai $\mathrm{IC}_{50}, 85.206$ ppmjika dibandingkan dengan vitamin $\mathrm{C}\left(\mathrm{IC}_{50}=\right.$ 4.939). Nilai $\mathrm{IC}_{50}$ ditentukan dengan cara mengalikan nilai konsentrasi pada tabel berdasarkan kurva standar asam askorbat dengan faktor pengenceran (fp) sebesar 10.

Tabel 3. Aktivitas Antioksidan

\begin{tabular}{|c|l|c|c|}
\hline No & \multicolumn{1}{|c|}{ Sampel } & Nilai IC & \\
\hline 1 & Daun Jembelu & $85.206 \mathrm{ppm}$ & Kriteria \\
\hline
\end{tabular}

Daun jembelu memiliki nilai $\mathrm{IC}_{50}$ yang lebih tinggi, berarti memiliki nilai aktivitas antioksidan yang rendah. Hal ini ditunjukkan keberadaan senyawa fenolik pada daun jembelu. Nurwaini et. al. (2006) menyatakan bahwa nilai aktivitas antioksidan yang tinggi dipengaruhi oleh kandungan fenolik pada sampel, jika semakin tinggi maka aktivitas antioksidannya juga makin tinggi yang ditunjukkan dengan nilai $\mathrm{IC}_{50}$.

Senyawa golongan fenol pada daun jembelu memiliki aktivitas antioksidan yang dapat mencegah radikal bebas di dalam tubuh sehingga sistem pertahanan tubuh semakin baik. Antioksidan yang terdapat dalam bahan pangan berfungsi dalam mencegah atau 
menghambat terjadinya kerusakan sel dalam tubuh akibat radikal bebas.

Senyawa metabolit sekunder pada daun jembelu memiliki aktivitas antioksidan yang rendah. Hal ini menunjukkan radikal bebas yang dapat dicegah di dalam tubuh juga rendah. Menurut Sandrasari (2008) bahwa jika aktivitas antioksidan tinggi maka radikal bebas yang dapat dicegah juga semakin tinggi.

Senyawa fenol dapat menangkal radikal bebas. Hal ini mengingat penangkapan radikal bebas DPPH dipengaruhi oleh gugus $\mathrm{OH}$ yang terdapat dalam senyawa fenolik. Menurut Yu Lin et. al. (2009) bahwa kemampuan penangkapan radikal bebas makin kuat jika gugus hidroksil yang tersubstitusi dalam molekul meningkat sehingga makin banyak atom hidrogen yang didonorkan.

Toripah et. al. (2014) menyatakan bahwa senyawa fenolik juga berperan dalam mendegradasi bakteri patogen dalam tubuh sehingga antioksidan merupakan zat antibodi sebagai daya tahan terhadap serangan bakteri.

Hasil perbandingan persen inhibisi dengan konsentrasi sampel menghasilkan persamaan garis $\mathrm{y}=0.3175 \mathrm{x}+22.947$ dengan $\mathrm{R} 2=0.9868$ sebagaimana tersaji pada Gambar 3.

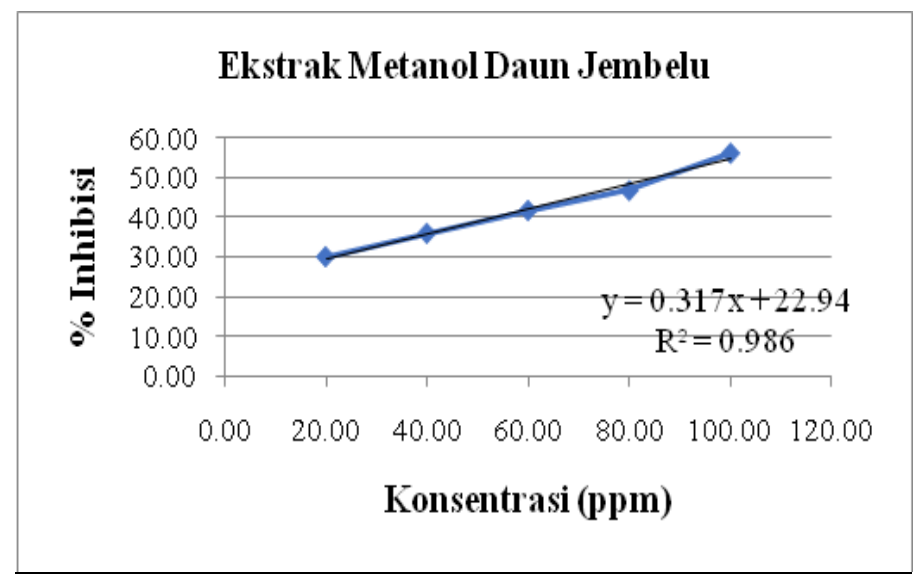

Gambar 3. Hasil Pengukuran Persen Inhibisi Ekstrak Daun Jembelu Terhadap DPPH

Berdasarkan data tersebut menunjukkan bahwa peningkatan konsentrasi ekstrak sampel cenderung meningkatkan persen inhibisi. Persen inhibisi tertinggi terdapat pada konsentrasi 100 ppm sebesar $56.14 \%$ kemudian menurun seiring berkurangnya konsentrasi ekstrak sampel.

Hasil perhitungan $\mathrm{IC}_{50}$ menunjukkan bahwa daun jembelu memiliki aktivitas antioksidan sebesar $85.206 \mathrm{ppm}$. Semakin tinggi nilai $\mathrm{IC}_{50}$, maka aktivitas antioksidan semakin rendah. Ria (2011) menyatakan bahwa beberapa faktor yang menyebabkan tinggi rendahnya aktivitas antioksidan dan fenol antara lain dipengaruhi oleh kemampuan dalam menyeimbangkan radikal bebas agar tidak terjadi kerusakan sel yang tinggi.

Senyawa dapat dinyatakan sebagai antioksidan kuat jika $\mathrm{IC}_{50}$, bernilai 50100 ppm, sedang jika nilai $\mathrm{IC}_{50}, 100-150$ ppm dan lemah jika $\mathrm{IC}_{50}, 151-200$ ppm (Zuhra et. al., 2008). Nilai $\mathrm{IC}_{50}$, yang rendah maka aktivitas antioksidan semakin tinggi.

Semakin tingginya aktivitas antioksidan dan polifenol disebabkan sifat redoks pada penerapan dan 
kemampuan menetralkan radikal bebas (Cao et. al., 1997).

Beberapa faktor yang mempengaruhi kandungan fenol pada daun antara lain umur daun, kondisi tanah, pemupukan dan kondisi lingkungan biologi, fisik, dan kimia (Kahkonen et. al., 2001). Dijelaskan oleh Nakiboglu et. Al. (2007) bahwa gugus $\mathrm{OH}$ da;am senyawa fenolik akan berperancdalam penangkapan radikal bebas DPPH. Selain itu struktur kimia, jumlah dan posisi gugus hidroksi dan metil pada cincin akan mempengaruhi penangkapan radikal bebas.

\section{KESIMPULAN}

Senyawa aktif yang terdapat dalam daun jembelu meliputi alkaloid, fenolik dan steroid.

Ekstrak metanol daun jembelu memiliki aktivitas antioksidan yang rendah dengan nilaiIC ${ }_{50}$, sebesar 85.206 ppm.

\section{UCAPAN TERIMA KASIH}

$\begin{array}{ccc}\text { Penulis } & \text { mengucapkan } & \text { terima } \\ \text { kasih } & \text { kepada } & \text { Yayasan Pembina }\end{array}$ Pendidikan Mahakam dan Universitas Widya Gama Mahakam yang telah memberi bantuan dana untuk kegiatan penelitian ini.

\section{DAFTAR PUSTAKA}

Cao, G.E., Sofic dan Priorr, R. L. (1997). Antioxidant dan Prooxidant Behavior of Flavonoid Structure Activity Relationships. Free Radical Biology and Medicine. USA. 22 (5): 749-760.
Kahkonen, M. P., Hopia, A., Heinonen. (2001). Berry Phenolics and Their Antioxidant Activity. J Agri Food Chem. 49: 9348-9351.

Lenny, S. (2006). Uji Bioaktifitas Kandungan Kimia Utama Puding Merah dengan Metode Brine Shirmp. Jurnal. Medan: USU.

Mukhlisi, Atmoko, T., Priyono. (2018). Flora di Habitat Bekantan Lahan Basah Suwi, Kalimantan Timur. Editor: Adi Susilo dan Sofian Iskandar. Forda Press, Bogor.

Nurwaini, S., Sofiana, Y.R., Noor, I.R., dan Rahayu, V. 2006. Uji Aktivitas Antiradikal Ekstrak Herba Cakar Ayam (Selaginella doederleinii Hieron), Herba Keladi Tikus (Typhonium divaricatum (L) Decne) dan Daun Eugenia uni $\square$ ora Linn Sebagai Sumber Alternatif Pencegahan Penyakit Degenatif, Laporan PKMP. 2 (18). 1-11.

Ria, O. R. (2011). Kandungan Fenol, Komponen Fitokimia, dan Aktivitas Antioksidan Lamun Enhalus eacoroides. Skripsi. Fakultas Perikanan dan Ilmu Kelautan. Institut Pertanian Bogor. Bogor.

Sandrasari, D. A. (2008). Kapasitas Antioksidan dan Hubungan Nilai Total Fenol Ekstrak Sayuran Indigenous. Tesis. Sekolah Pascasarjana. Institut Pertanian Bogor.

Winarsi, H. (2007). Antioksidan Alami dan Radikal Bebas. Yogyakarta: Kanisius. 
Yu Lin, H., Kuo, Y.H., Lin, Y.L., Chiang, W. (2009). Antioxidative effect and active componens from leaves of Lotus (Nelumbo necifera). Journal of Agricultural and Food Chemistry. 57. 66236629.
Zuhra, C. F., Juliati, T.B. dan Herlince, S. (2008). Aktivitas Antioksidan Senyawa Flavonoid dari Daun Katuk. Jurnal Biologi Sumatera. Sumatera. 